\title{
Kinesin gene variability may affect tau phosphorylation in early Alzheimer's disease
}

\author{
MALIN E. ANDERSSON ${ }^{1}$, ANNICA SJÖLANDER ${ }^{1}$, NIELS ANDREASEN ${ }^{2}$, \\ LENNART MINTHON ${ }^{3,4}$, OSKAR HANSSON ${ }^{3,4}$, NENAD BOGDANOVIC ${ }^{2}$, CHRISTINA JERN ${ }^{5}$, \\ KATARINA JOOD ${ }^{5}$, ANDERS WALLIN ${ }^{1}$, KAJ BLENNOW ${ }^{1,6}$ and HENRIK ZETTERBERG ${ }^{1,6}$
}

\begin{abstract}
${ }^{1}$ Institute of Neuroscience and Physiology, Department of Psychiatry and Neurochemistry, the Sahlgrenska Academy at Göteborg University, Göteborg; ${ }^{2}$ Neurotec Department, Section of Clinical Geriatrics, Karolinska Institutet, Karolinska University Hospital in Huddinge, Stockholm; ${ }^{3}$ Clinical Memory Research Unit, Department of Clinical Sciences Malmö, Lund University; ${ }^{4}$ Neuropsychiatric Clinic, Malmö University Hospital; ${ }^{5}$ Institute of Neuroscience and Physiology, Department of Clinical Neuroscience and Rehabilitation, and ${ }^{6}$ Institute of Biomedicine, Department of Clinical Chemistry and Transfusion Medicine, the Sahlgrenska Academy at Göteborg University, Göteborg, Sweden
\end{abstract}

Received March 13, 2007; Accepted April 19, 2007

\begin{abstract}
Kinesin is a microtubule-associated motor protein that transports Alzheimer-associated amyloid precursor protein (APP) in neurons. In animal models, impaired kinesin-mediated APP transport seems to enhance formation of the neurotoxic 42 amino acid fragment of $\beta$-amyloid (Aß42). In man, one study suggests that a polymorphism (rs8702, 56,836G $>C$ ) in the kinesin light chain 1 gene (KNS2) may affect the risk of Alzheimer's disease (AD). To further assess KNS2 as a susceptibility gene for $\mathrm{AD}$ we analyzed 802 patients with sporadic AD and 286 controls, 134 longitudinally followed patients with mild cognitive impairment (MCI) and 39 cognitively stable controls for the rs8702 polymorphism. The rs8702 polymorphism did not influence risk of AD ( $\mathrm{p}=0.46)$. However, rs8702 interacted with APOE \&4 carrier status in AD $(\mathrm{p}=0.006)$ and influenced cerebrospinal fluid levels of hyperphosphorylated tau in MCI patients who converted to AD during follow-up $(\mathrm{p}=0.018)$. These findings support earlier indications that genetic variability in the KNS2 gene may play a role during early stages of $\mathrm{AD}$ pathogenesis.
\end{abstract}

\section{Introduction}

Alzheimer's disease (AD) is a neurodegenerative disorder resulting in progressive cognitive impairment. The pathological hallmarks of $\mathrm{AD}$ are the presence of intracellular

Correspondence to: Dr Henrik Zetterberg, Department of Neurochemistry, Sahlgrenska University Hospital/Mölndal, S-431 80 Mölndal, Sweden

E-mail: henrik.zetterberg@clinchem.gu.se

Key words: Alzheimer's disease, kinesin, polymorphism, biomarkers, apolipoprotein E, axonal transport neurofibrillary tangles of hyperphosphorylated protein tau and extracellular deposits of amyloid B-protein (AB) in senile plaques in the cerebral cortex. Although these brain lesions are seen in aged non-demented individuals, the accumulation of $A B$ in the brain is believed by many to represent the earliest event in the pathogenesis of $A D(1) . A B$ is generated from amyloid precursor protein (APP), a type I integral membrane protein with one transmembrane domain, by enzymatic digestion involving $\beta$ - and $\gamma$-secretase activities. The amyloid cascade hypothesis is supported by a wealth of genetic and biochemical data, especially for the familial forms of the disease (2). However, what starts $A B$ aggregation in sporadic $\mathrm{AD}$ remains an open question. Some data suggest that a primary alteration in the axonal compartment might be the initiating event (3). Hypothetically, a primary cause of sporadic AD might be dysfunctional axonal transport that leads to increased production of $\mathrm{A} B$ and tau hyperphosphorylation, which further damage axonal transport in an autocatalytic and neurotoxic loop.

Kinesin is an ATP-dependent motor enzyme that travels along microtubules in a plus-ended direction and transports cargoes to the periphery of the cell (4). It is composed of two subunits. The first is the kinesin heavy chain protein encoded by the KNS1 gene and contains the ATP- and microtubulebinding motifs that are essential for vesicle transport. The second is the kinesin light chain 1 (KLC1) protein encoded by the KNS 2 gene. This component associates with the heavy chain and with membrane vesicles that are transported along the axon from the neuronal cell body to nerve terminals (4). A number of observations suggest that impaired kinesin function may be specifically involved in the AD process. Firstly, KLC1 and APP exhibit high-affinity biochemical interaction (5-7). Secondly, in neurons, APP and its proteolytic machinery, $\beta$ - and $\gamma$-secretase, undergo kinesin-mediated fast anterograde axonal transport during which APP is proteolytically processed (6,8-10). Thirdly, reduced KLC1 dosage in mutant mice is associated with increased $A ß$ generation in 
axonal swellings (11). Fourthly, overexpression of APP in Drosophila causes axonal transport defects that are markedly enhanced by reductions in the amount of kinesin (12). Finally, APP, A $\beta$, kinesin, $\beta$ - and $\gamma$-secretase accumulate in axonal swellings during brain aging and after traumatic brain injury, and eventually form senile plaque-like aggregates that may represent early stages of AD (13-15).

Recently, a study including 100 neuropathologically confirmed AD patients and 103 non-demented controls revealed a possible association with one of three examined single nucleotide polymorphisms (SNPs) in the KLC1encoding KNS2 gene. The C allele of the polymorphism rs $8702(56,836 \mathrm{G}>\mathrm{C})$, located in intron 13 of the KNS2 gene, was significantly overrepresented among AD patients (16). To further investigate this association, we analyzed the clinical material of 802 patients with sporadic AD and 286 controls, 134 longitudinally followed patients with mild cognitive impairment (MCI) and 39 cognitively stable controls for the KNS2 rs8702 polymorphism. Apart from risk, our analysis was complemented with an evaluation of possible effects of the KNS2 marker on quantitative biomarker traits that may reflect elements of AD pathology. Furthermore, we tested the hypothesis that KNS2 might interact with the major susceptibility gene for $\mathrm{AD}$, the apolipoprotein $\mathrm{E}(\mathrm{APOE})$ gene, to influence risk of $\mathrm{AD}$.

\section{Materials and methods}

Participants. The study included 3 Swedish population groups (sets A-C). Set A consisted of clinically diagnosed AD patients $(n=719)$ and controls $(n=187)$ and neuropathologically diagnosed AD patients $(n=83)$ and controls $(n=99)$. Set B consisted of clinically diagnosed MCI patients and controls (17) and set C of healthy control subjects from a Swedish stroke study (18) (Table I). The study was approved by the ethics committees at the Universities of Göteborg, Lund and Umeå, Sweden. The patients (or their closest relatives) and the control subjects gave informed consent to participate in the study, which was conducted in accordance with the provisions of the Helsinki Declaration.

Patients in set A were clinically diagnosed with probable late-onset $\mathrm{AD}$ according to the National Institute of Neurological Disorders and Stroke - Association Internationale pour la Recherche et l'Enseignement en Neurosciences) (NINCDS-ADRDA) criteria (19). AD diagnosis was preceded by detailed clinical investigation including medical history, physical, neurological and psychiatric examination, screening laboratory tests, ECG, EEG, chest x-ray and computed tomography of the brain. All clinical evaluations were made without knowledge of the results from the biochemical and genetic analyses and vice versa. MiniMental State Examination (MMSE) was performed according to Folstein and co-workers (20). No patient had a family history of autosomal dominant dementia. Control cases had no history of dementia and did not show any signs of psychiatric illness, malignant disease or systematic disorder. Potential control subjects with MMSE scores <28 were not included in the control group. AD patients in the post mortem material were diagnosed with probable late-onset $\mathrm{AD}$ according to the NINCDS-ADRDA criteria and the diagnosis was confirmed
Table I. Descriptive data for the populations studied.

\begin{tabular}{lcrcc}
\hline & Population & $\begin{array}{c}\text { No. of } \\
\text { subjects }\end{array}$ & $\begin{array}{c}\text { Sex } \\
(\mathrm{M} / \mathrm{F})\end{array}$ & $\begin{array}{c}\text { Age } \\
(\text { mean } \pm \text { SD })\end{array}$ \\
\hline Set A & Swedish & & & \\
AD & & 802 & $293 / 509$ & $76 \pm 7.0$ \\
Controls & & 286 & $117 / 169$ & $72 \pm 9.2$ \\
Set B & Swedish & & & \\
Early AD & & 57 & $16 / 41$ & $74 \pm 5.9$ \\
Controls & & 39 & $15 / 24$ & $72 \pm 7.7$ \\
Stable MCI & & 56 & $30 / 26$ & $64 \pm 9.0$ \\
Progressing to & & 21 & $13 / 8$ & $73 \pm 9.3$ \\
other dementias & & & & \\
Set C & Swedish & & & \\
Healthy controls & & 593 & $379 / 214$ & $56 \pm 10.3$ \\
\hline
\end{tabular}

$\mathrm{AD}$, Alzheimer's disease; MCI, mild cognitive impairment; SD, standard deviation.

upon neuropathological examination of the brain (21). None showed infarcts or other brain changes that could have caused the dementia. Control cases did not have a history of dementia, psychiatric or malignant disease. All controls fulfilled the requirements of histopathological scores $<4.0$ (21).

Sets B and C have been described elsewhere $(17,18)$. In brief, set B consisted of 134 patients with MCI and 39 controls. At baseline, patients underwent physical, neurological and psychiatric examination, careful clinical history and functional assessment. Moreover, computed tomography of the brain and cognitive tests were performed. The criteria of MCI were those defined by Petersen and collaborators (22), which include: (i) memory complaint, preferably corroborated by an informant, (ii) objective memory impairment adjusted for age and education, (iii) preservation of general cognitive functioning, (iv) no or minimal impairment of daily life activities, and (v) not fulfilling the DSM-IIIR (Diagnostic and Statistical Manual of Mental Disorders, 3rd edition, revised) criteria of dementia (23). The patients were followed clinically at least until they developed a certain type of dementia or until they had been cognitively stable for more than 4 years (average 5.2 years; range 4.0-6.8 years). The patients who received a diagnosis of $\mathrm{AD}$ during follow-up were required to meet the DSM-IIIR criteria of dementia (23) and the criteria of probable AD defined by NINCDS-ADRDA (19). The patients who received a diagnosis of vascular dementia (VaD) fulfilled the DSM-IIIR criteria of dementia (23) and the requirements of NINDS-AIREN (National Institute of Neurological Disorders and Stroke - Association Internationale pour la Recherche et l'Enseignement en Neurosciences) for probable $\mathrm{VaD}$ (24). For patients who developed dementia with Lewy bodies or frontotemporal dementia the consensus criteria by McKeith and collaborators (25) and Brun and colleagues (26) were used, respectively. Additionally, 39 healthy individuals, cognitively stable over 3 years, served as controls. 
Table II. MMSE, CSF data and APOE genotype frequencies for AD and control populations.

\begin{tabular}{|c|c|c|c|}
\hline & $\mathrm{AD}$ & Controls & p-value \\
\hline \multicolumn{4}{|l|}{ Cognition } \\
\hline MMSE (mean \pm SEM) & $21.6 \pm 0.2$ & $29.2 \pm 0.1$ & $<0.001$ \\
\hline \multicolumn{4}{|l|}{ Biomarkers } \\
\hline $\mathrm{A} ß 42($ mean $\pm \mathrm{SEM}, \mathrm{ng} / \mathrm{l})$ & $457 \pm 6.6(n=585)$ & $712 \pm 14.8(n=161)$ & $<0.001$ \\
\hline T-tau (mean \pm SEM, ng/l) & $668 \pm 12.8(n=599)$ & $351 \pm 12.2(\mathrm{n}=161)$ & $<0.001$ \\
\hline P-tau (mean \pm SEM, ng/l) & $81.4 \pm 1.4(\mathrm{n}=567)$ & $62.1 \pm 1.6(n=131)$ & $<0.001$ \\
\hline \multicolumn{4}{|l|}{$A P O E$ genotype frequencies } \\
\hline No $\varepsilon 4[\mathrm{n}(\%)]$ & $253(31.5)$ & 199 (69.6) & \\
\hline One $\varepsilon 4[\mathrm{n}(\%)]$ & $414(51.6)$ & $78(27.3)$ & \\
\hline Two $\varepsilon 4[\mathrm{n}(\%)]$ & $135(16.8)$ & $9(3.2)$ & $<0.001$ \\
\hline
\end{tabular}

MMSE, Mini-Mental State Examination; CSF, cerebrospinal fluid; APOE, apolipoprotein E; SEM, standard error of the mean.

Table III. KNS2 rs8702 genotype and allele frequencies in $\mathrm{AD}$ patients and controls.

$\begin{array}{ccc}\mathrm{AD} & \text { Controls } & \text { p-value } \\ {[\mathrm{n}(\%)]} & {[\mathrm{n}(\%)]} & \end{array}$

KNS2 rs 8702

genotype frequencies

$\begin{array}{lccc}\text { GG } & 413(51.5) & 147(51.4) & \\ \text { GC } & 324(40.4) & 122(42.7) & \\ \text { CC } & 65(8.1) & 17(5.9) & 0.46\end{array}$

KNS2 rs 8702

allele frequencies

\begin{tabular}{lrrr}
$\mathrm{G}$ & $1150(71.7)$ & $416(72.7)$ & \\
$\mathrm{C}$ & $454(28.3)$ & $156(27.3)$ & 0.64 \\
\hline
\end{tabular}

KNS2, the kinesin light chain 1 gene; AD, Alzheimer's disease.

Set $\mathrm{C}$ consisted of healthy individuals randomly selected from participants in a population-based health survey (27) or the Swedish Population Register. Exclusion criteria were history or signs of vascular disease and dementing illness (18).

CSF sampling and biomarker analysis. Approximately $12 \mathrm{ml}$ of CSF was collected by lumbar puncture through the L3/L4 or L4/L5 interspace in polypropylene tubes. Further details are described elsewhere (28). CSF samples were stored at $-80^{\circ} \mathrm{C}$ pending analysis. Determination of CSF total tau (T-tau), tau phosphorylated at threonine 181 (P-tau) and the 42 amino acid fragment of $A ß$ (Aß42) was performed using immunoassays as previously described (17,29-31).

Genetic analyses. Gene symbols used in this study follow the recommendations of the HUGO Gene Nomenclature Committee (32). Genomic DNA for set A and B was obtained from $100 \mu \mathrm{l}$ whole blood or from $10 \mathrm{mg}$ brain tissue using a
GenoPrep $^{\mathrm{TM}}$ DNA Blood kit and DNA MagAttract kit (Qiagen, Germany) with GenoM ${ }^{\mathrm{TM}}-48$ Robotic Workstation (Geno Vision, Norway). Genomic DNA for set C was extracted from peripheral blood using a mini column method in single tube or 96-well microtiter well format (QIAamp ${ }^{\circledR}$ DNA Blood Mini kit and QIAamp ${ }^{\circledR} 96$ DNA Blood kit; Qiagen). DNA was stored at $-20^{\circ} \mathrm{C}$ pending analysis.

$A P O E$ genotyping was performed by minisequencing as described previously in detail (33). Genotypes were obtained for the two SNPs, which are used to unambiguously define $\varepsilon 2, \varepsilon 3$, and $\varepsilon 4$ alleles (rs7412 and rs429358).

Primers for Dynamic Allele-Specific Hybridization (DASH) and sequence PCRs enclosing KNS2 rs8702 and DASH probes were designed using sequence information deposited in the UCSC genome browser (http://genome.ucsc.edu). DNA for DASH analysis was amplified using AmpliTaq Gold ${ }^{\circledR}$ (Applied Biosystems, Branchburg, NJ, USA) under optimal conditions: $3.0 \mathrm{mM} \mathrm{MgCl}, 0.16 \mathrm{pmol} / \mu 1$ forward primer (Biotin-TGAC GGTGACCTGTTGACGAAA), $0.64 \mathrm{pmol} / \mu 1$ reverse primer (GAGCACGTGCGGCACATTC) (Invitrogen, Life Technologies) and $52.5^{\circ} \mathrm{C}$ hybridization temperature. Genotyping of the SNP was performed using the C probe CTTGCTCTA AGGCTTAG-rox (MWG Biotech, London, UK).

The accuracy of the DASH method was verified by DNA sequencing of 23 samples representing all three genotypes. DNA for sequencing was amplified using Taq DNA polymerase (Roche Diagnostics, Mannheim, Germany) under the optimal conditions of $1.5 \mathrm{mM} \mathrm{MgCl}_{2}, 0.4 \mathrm{pmol} / \mu 1$ primers (forward: AGCTGTTCACTTTGGTAACAGG, reverse: TGCTACTGGGGCATATCCTAG; Invitrogen, Life Technologies) and $56.4^{\circ} \mathrm{C}$ hybridization temperature. PCR products were purified using MicroSpin ${ }^{\mathrm{TM}} \mathrm{S}-300 \mathrm{HR}$ Columns (Amersham Biosciences, Buckinghamshire, UK). Sequencing reactions were run in sense and anti-sense direction using cycle sequencing with fluorescent dNTPs (ABI PRISM Big Dye Terminator Cycle Sequencing Ready Reaction Kit 3.1; Applied Biosystems, UK). Separation by capillary electrophoresis and detection by laser-induced fluorescence was performed with an ABI PRISM 3100 genetic analyzer (Applied Biosystems, USA). 
Table IV. Descriptive data and CSF biomarker levels in AD patients according to KNS2 rs8702 genotype.

\begin{tabular}{lcccc}
\hline & & KNS2 rs8702 & CC & p-value \\
\cline { 2 - 4 } & GG & GC & & \\
Descriptive data & & 324 & 65 & 0.076 \\
No. of subjects & 413 & $133 / 191$ & $24 / 41$ & 0.55 \\
Gender (M/F) & $136 / 277$ & $76 \pm 7.1$ & $76 \pm 4.5$ & 0.62 \\
Age (mean \pm SD) & $76 \pm 7.1$ & $21.7 \pm 0.3$ & $21.4 \pm 0.66$ & \\
MMSE (mean \pm SEM) & $21.6 \pm 0.3$ & & $491 \pm 29.4(\mathrm{n}=45)$ & 0.54 \\
Biomarkers & & $451 \pm 9.8(\mathrm{n}=240)$ & $634 \pm 42.8(\mathrm{n}=45)$ & 0.51 \\
Aß42 (mean \pm SEM, ng/l) & $456 \pm 9.2(\mathrm{n}=300)$ & $658 \pm 19.2(\mathrm{n}=243)$ & $80.3 \pm 6.0(\mathrm{n}=43)$ \\
T-tau (mean \pm SEM, ng/l) & $680 \pm 18.6(\mathrm{n}=311)$ & $80.3 \pm 2.1(\mathrm{n}=236)$ & 0.52 \\
P-tau (mean \pm SEM, ng/l) & $82.5 \pm 2.0(\mathrm{n}=288)$ & & \\
\hline
\end{tabular}

CSF, cerebrospinal fluid; AD, Alzheimer's disease; KNS2, the kinesin light chain 1 gene; MMSE, Mini-Mental State Examination; SD, standard deviation; SEM, standard error of the mean.

Table V. Gene-gene interaction between KNS2 and APOE.

\begin{tabular}{|c|c|c|c|c|}
\hline & No $A P O E \varepsilon 4[\mathrm{n}(\%)]$ & One $A P O E \varepsilon 4[\mathrm{n}(\%)]$ & Two $A P O E \varepsilon 4[\mathrm{n}(\%)]$ & $\mathrm{p}$-value \\
\hline \multicolumn{5}{|c|}{ AD patients } \\
\hline \multicolumn{5}{|c|}{ KNS2 rs8702 genotype frequencies } \\
\hline GG & $114(45)$ & $223(53.9)$ & $76(56.3)$ & \\
\hline GC & $112(44.3)$ & $155(37.4)$ & $57(42.2)$ & \\
\hline $\mathrm{CC}$ & $27(10.7)$ & $36(8.7)$ & $2(1.5)$ & 0.006 \\
\hline \multicolumn{5}{|c|}{ KNS2 rs8702 allele frequencies } \\
\hline $\mathrm{G}$ & $340(67.2)$ & $601(72.6)$ & $209(77.4)$ & \\
\hline $\mathrm{C}$ & $166(32.8)$ & $227(27.4)$ & $61(22.6)$ & 0.008 \\
\hline \multicolumn{5}{|c|}{ Non-demented controls } \\
\hline \multicolumn{5}{|c|}{ KNS2 rs8702 genotype frequencies } \\
\hline GG & $224(54.2)$ & $92(56.1)$ & $6(37.5)$ & \\
\hline GC & $154(37.3)$ & $61(37.2)$ & $6(37.5)$ & \\
\hline $\mathrm{CC}$ & $35(8.48)$ & $11(6.71)$ & $4(25.0)$ & 0.15 \\
\hline \multicolumn{5}{|c|}{ KNS2 rs8702 allele frequencies } \\
\hline $\mathrm{G}$ & $602(72.9)$ & $245(74.7)$ & $18(56.3)$ & \\
\hline $\mathrm{C}$ & $224(27.1)$ & $83(25.3)$ & $14(43.8)$ & 0.081 \\
\hline
\end{tabular}

$\mathrm{AD}$, Alzeimer's disease; KNS2, the kinesin light chain 1 gene; $A P O E$, the apolipoprotein E gene.

Statistical analysis. Deviation from Hardy-Weinberg equilibrium for alleles at individual loci as well as differences in allele and genotype distributions between groups were assessed by the $\chi^{2}$ statistics. As the distribution of most quantitative measures was significantly skewed, all statistical tests involving quantitative variables were conducted using nonparametric Kruskal-Wallis analysis of ranks. All statistical calculations were performed using SYSTAT 11.0 (SYSTAT Software $\mathrm{GmbH}$, Erkrath, Germany). The power of the study for detecting the difference in rs8702 $\mathrm{C}$ allele frequency between
$\mathrm{AD}$ cases and controls found by Dhaenens and co-workers (16) was $>95 \%$ after correction for unequal sample size.

\section{Results}

We began by confirming the well-replicated finding of association between genetic variants of $A P O E$ and $\mathrm{AD}$. AD patients had a significantly higher number of $A P O E \& 4$ alleles than controls ( $p<0.001$, Table II). CSF A 342 levels were lower in $\mathrm{AD}$ patients than control subjects $(\mathrm{p}<0.001)$, while $\mathrm{T}$-tau and 
Table VI. KNS2 genotype and allele frequencies in APOE $\varepsilon 4$-positive and -negative AD patients and controls.

\begin{tabular}{|c|c|c|c|}
\hline & $\mathrm{AD}$ & Controls & p-value \\
\hline \multicolumn{4}{|c|}{$A P O E \& 4$-positive individuals } \\
\hline \multicolumn{4}{|c|}{ KNS2 rs8702 genotype frequencies } \\
\hline GG & $299(54.5)$ & $49(56.3)$ & \\
\hline $\mathrm{GC}$ & $212(38.6)$ & $33(37.9)$ & \\
\hline $\mathrm{CC}$ & $38(6.9)$ & $5(5.7)$ & 0.90 \\
\hline \multicolumn{4}{|c|}{ KNS2 rs8702 allele frequencies } \\
\hline $\mathrm{G}$ & $810(73.7)$ & $131(75.3)$ & \\
\hline $\mathrm{C}$ & $288(26.2)$ & $43(24.7)$ & 0.67 \\
\hline \multicolumn{4}{|c|}{ APOE $\varepsilon 4$-negative individuals } \\
\hline \multicolumn{4}{|c|}{ KNS2 rs8702 genotype frequencies } \\
\hline GG & $114(45.1)$ & $98(49.2)$ & \\
\hline $\mathrm{GC}$ & $112(44.3)$ & $89(44.7)$ & \\
\hline $\mathrm{CC}$ & $27(10.7)$ & $12(6.0)^{\mathrm{a}}$ & 0.20 \\
\hline \multicolumn{4}{|c|}{ KNS2 rs8702 allele frequencies } \\
\hline G & $340(67.2)$ & $285(71.6)$ & \\
\hline $\mathrm{C}$ & $166(32.8)$ & $113(28.4)$ & 0.15 \\
\hline
\end{tabular}

$\mathrm{AD}$, Alzeimer's disease; KNS2, the kinesin light chain 1 gene; $A P O E$, the apolipoprotein $\mathrm{E}$ gene. ${ }^{\mathrm{a}} \mathrm{P}=0.081$ when comparing the CC genotype frequency in $\varepsilon 4$-negative $\mathrm{AD}$ cases and controls.

P-tau concentrations were significantly elevated $(\mathrm{p}<0.001$, Table II).

KNS2 genotype and allele frequencies were in HardyWeinberg equilibrium and were not significantly different between AD cases and controls (Table III). There was no association between KNS2 genotype and biological markers for $\mathrm{AD}$ (Table IV). However, when analyzing KNS2 genotype frequencies in $\mathrm{AD}$ patients with different numbers of $A P O E \varepsilon 4$ alleles, an interaction between $K N S 2$ and $A P O E$ was revealed (Table V). Inheritance of one or two $\varepsilon 4$ alleles was associated with a gene dose-dependent decrease in the KNS2 rs8702 C allele frequency. Next, we questioned whether this was an $\mathrm{AD}$-specific phenomenon. The control group in set $\mathrm{A}$ had too few $\varepsilon 4$ homozygotes to address this question. Instead, we analyzed an unrelated healthy control population from a Swedish stroke study (set C, Table I). The data showed that the interaction was not present in this non-AD cohort (Table V). When stratifying set A into $A P O E$ \&4-positive and -negative individuals (Table VI), a tendency was seen that the rs8702 $\mathrm{CC}$ genotype might contribute to risk of $\mathrm{AD}$ in $\varepsilon 4$-negative individuals $(\mathrm{p}=0.081$, Table VI).

Finally, we questioned whether the KNS2 rs8702 polymorphism might influence molecular changes in the early disease process, i.e. in AD in its MCI stage. The rs8702 C allele was significantly and gene dose-dependently associated with elevated concentrations of P-tau, specifically in MCI patients who progressed to $\mathrm{AD}(\mathrm{p}=0.018$, Fig. 1). T-tau levels were affected in a similar manner $(\mathrm{p}=0.050$, Fig. 1$)$, while A 342 levels were comparable in the three KNS2 genotype groups. The rs8702 $\mathrm{C}$ allele did not show association with increased P-tau or T-tau levels in MCI patients who were

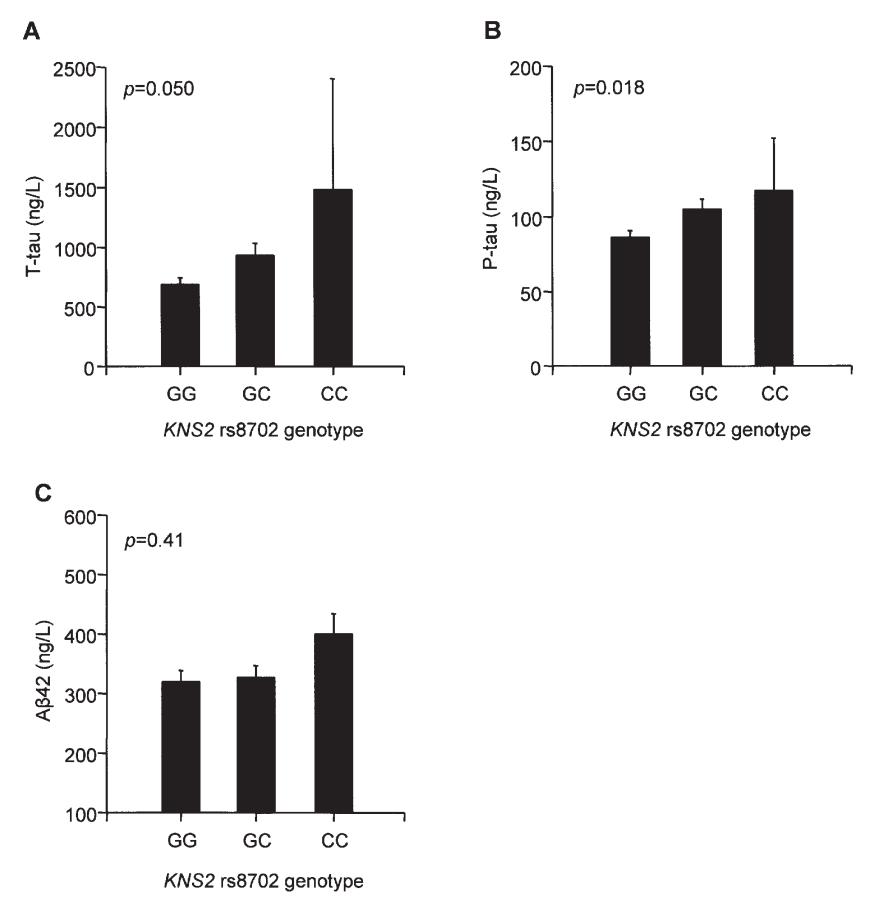

Figure 1. T-tau (A), P-tau (B) and Aß42 (C) levels according to the KNS2 rs8702 genotypes GG $(n=32), G C(n=23)$ and $C C(n=2)$ in MCI patients who progressed to $\mathrm{AD}$ during follow-up. Values are means and error bars indicate standard errors of the mean (SEM).

cognitively stable or in MCI patients who progressed to other forms of dementia or in the cognitively stable controls (data not shown). 


\section{Discussion}

$\mathrm{AD}$ has been the subject of numerous gene association studies (34). While many positive findings for candidate genes have been reported, none exhibits an effect as large and consistent as that of the $A P O E$ gene $(35,36)$. Here, we attempted to replicate the recent finding in a small but autopsy-confirmed case-control cohort that the KNS2 rs8702 C allele may be associated with increased risk of AD (16).

The KNS2 rs8702 C allele frequency in our control and study populations (27\% and $28 \%$, respectively) was similar to that found by Dhaenens et al when grouping their patients and controls (29\%) (16). Our results showed no influence of the KNS2 rs8702 polymorphism on risk of $\mathrm{AD}$, neither in the whole population, nor in the neuropathologically confirmed subset that had a size similar to the groups in the study by Dhaenens et al (16). However, an association between the rs8702 $\mathrm{C}$ allele and tau hyperphosphorylation in early AD was revealed, which suggests an involvement of kinesin gene variability in the $\mathrm{AD}$ process once it has started.

Kinesin function is regulated by alternative splicing and phosphorylation of C-terminal epitopes. There are at least 19 variants of human KNS2 gene transcripts that are generated by alternative splicing of downstream exons (37). The alternative exons are all located $3^{\prime}$ of exon 12 and the different splice forms produce both alternative $\mathrm{C}$-termini and alternative 3 ' untranslated regions. Intron 13, in which rs 8702 is located, may contain important sequences regulating this process. Interestingly, both tau and KLC1 are known in vivo substrates for glycogen synthase kinase-3ß (GSK3ß) $(38,39)$. The major phosphorylation epitopes in KLC1 are located in the $\mathrm{C}$-terminal domains and hyperphosphorylation leads to KLC1 detachment from microtubules and impaired axonal transport (38). Similarly, tau hyperphosphorylation leads to its detachment from the microtubules and may either be a consequence of or result in microtubule destabilization and axonal dysfunction. Alternative splicing that skips GSK3ß consensus motif-containing KLC1 exons would possibly result in different KLC1 isoforms with different susceptibility to the GSK3ß activation seen in AD brains (40). This might also explain the association between the KNS2 rs8702 polymorphism and hyperphosphorylation of tau. However, this hypothesis needs to be evaluated in future studies.

The gene-gene interaction between $A P O E$ located on chromosome 19 and KNS2 located on chromosome 14 was an unexpected finding. The combined KNS2 rs8702 CC and $A P O E \varepsilon 4 / \varepsilon 4$ genotype was significantly underrepresented in the $\mathrm{AD}$ cohort and there was a dose-dependent decrease in the $\mathrm{C}$ allele frequency with increasing numbers of $\varepsilon 4$ alleles. This interaction was not present in unrelated control material. Possibly, rs8702 C carriers are less susceptible to the ADpromoting effect of the APOE $\varepsilon 4$ allele. However, we consider this unlikely in the light of the results that the $\mathrm{C}$ allele is associated with tau hyperphosphorylation and that the rs 8702 $\mathrm{CC}$ genotype might impose an increased risk of $\mathrm{AD}$ in $\varepsilon 4-$ negative individuals. The functional basis for the APOE-KNS2 gene interaction is at this stage difficult to discuss and the finding warrants independent confirmation.
Altogether, our results do not support KNS2 as a major susceptibility gene for $\mathrm{AD}$. Nonetheless, genetic variation in the KNS2 gene may influence AD-specific tau hyperphosphorylation early in the disease process. Thus, genetic variability in KNS2 may affect the course of the disease, once its process has started.

\section{Acknowledgements}

We thank Mona Seibt Palmér for skillful technical assistance. This study was supported by grants from the Swedish Research Council, the Swedish Council for Working Life and Social Research, the Göteborg Medical Society, the Swedish Society for Medical Research, the Royal Swedish Academy of Sciences, the Fredrik and Ingrid Thuring Foundation, the Gamla Tjänarinnor Foundation, the Åke Wiberg Foundation, the Gun and Bertil Stohne Foundation, the Magn. Bergvall Foundation, the Ragnar and Einar Lundström Foundation and Pfizer Inc. The sponsors of the study had no role in study design, data collection, data analysis, data interpretation, or writing of the report.

\section{References}

1. Blennow K, de Leon MJ and Zetterberg H: Alzheimer's disease. Lancet 368: 387-403, 2006.

2. Hardy J and Selkoe DJ: The amyloid hypothesis of Alzheimer's disease: progress and problems on the road to therapeutics. Science 297: 353-356, 2002.

3. Terry RD: The pathogenesis of Alzheimer disease: an alternative to the amyloid hypothesis. J Neuropathol Exp Neurol 55: 1023-1025, 1996.

4. Stokin GB and Goldstein LS: Axonal transport and Alzheimer's disease. Annu Rev Biochem 75: 607-627, 2006.

5. Inomata H, Nakamura Y, Hayakawa A, Takata H, Suzuki T, Miyazawa K and Kitamura N: A scaffold protein JIP-1b enhances amyloid precursor protein phosphorylation by JNK and its association with kinesin light chain 1. J Biol Chem 278: 22946-22955, 2003.

6. Kamal A, Stokin GB, Yang Z, Xia CH and Goldstein LS: Axonal transport of amyloid precursor protein is mediated by direct binding to the kinesin light chain subunit of kinesin-I. Neuron 28: 449-459, 2000.

7. Matsuda S, Matsuda Y and D'Adamio L: Amyloid beta protein precursor (AbetaPP), but not AbetaPP-like protein 2, is bridged to the kinesin light chain by the scaffold protein JNK-interacting protein 1. J Biol Chem 278: 38601-38606, 2003.

8. Amaratunga A, Leeman SE, Kosik KS and Fine RE: Inhibition of kinesin synthesis in vivo inhibits the rapid transport of representative proteins for three transport vesicle classes into the axon. J Neurochem 64: 2374-2376, 1995.

9. Kaether C, Skehel P and Dotti CG: Axonal membrane proteins are transported in distinct carriers: a two-color video microscopy study in cultured hippocampal neurons. Mol Biol Cell 11: 1213-1224, 2000.

10. Kamal A, Almenar-Queralt A, LeBlanc JF, Roberts EA and Goldstein LS: Kinesin-mediated axonal transport of a membrane compartment containing beta-secretase and presenilin-1 requires APP. Nature 414: 643-648, 2001.

11. Stokin GB, Lillo C, Falzone TL, Brusch RG, Rockenstein E, Mount SL, Raman R, Davies P, Masliah E, Williams DS and Goldstein LS: Axonopathy and transport deficits early in the pathogenesis of Alzheimer's disease. Science 307: 1282-1288, 2005.

12. Gunawardena S and Goldstein LS: Disruption of axonal transport and neuronal viability by amyloid precursor protein mutations in Drosophila. Neuron 32: 389-401, 2001.

13. Chen XH, Siman R, Iwata A, Meaney DF, Trojanowski JQ and Smith DH: Long-term accumulation of amyloid-beta, betasecretase, presenilin-1, and caspase-3 in damaged axons following brain trauma. Am J Pathol 165: 357-371, 2004. 
14. Kawarabayashi T, Shoji M, Yamaguchi H, Tanaka M, Harigaya Y, Ishiguro $\mathrm{K}$ and Hirai S: Amyloid beta protein precursor accumulates in swollen neurites throughout rat brain with aging. Neurosci Lett 153: 73-76, 1993.

15. Smith DH, Chen XH, Iwata A and Graham DI: Amyloid beta accumulation in axons after traumatic brain injury in humans. J Neurosurg 98: 1072-1077, 2003.

16. Dhaenens CM, Van Brussel E, Schraen-Maschke S, Pasquier F, Delacourte A and Sablonniere B: Association study of three polymorphisms of kinesin light-chain 1 gene with Alzheimer's disease. Neurosci Lett 368: 290-292, 2004.

17. Hansson O, Zetterberg H, Buchhave P, Londos E, Blennow K and Minthon L: Association between CSF biomarkers and incipient Alzheimer's disease in patients with mild cognitive impairment: a follow-up study. Lancet Neurol 5: 228-234, 2006.

18. Jood K, Ladenvall C, Rosengren A, Blomstrand C and Jern C: Family history in ischemic stroke before 70 years of age: the Sahlgrenska Academy Study on Ischemic Stroke. Stroke 36: 1383-1387, 2005

19. McKhann G, Drachman D, Folstein M, Katzman R, Price D and Stadlan EM: Clinical diagnosis of Alzheimer's disease: report of the NINCDS-ADRDA Work Group under the auspices of Department of Health and Human Services Task Force on Alzheimer's Disease. Neurology 34: 939-944, 1984.

20. Folstein MF, Folstein SE and McHugh PR: 'Mini-mental state' A practical method for grading the cognitive state of patients for the clinician. J Psychiatr Res 12: 189-198, 1975.

21. Alafuzoff I, Iqbal K, Friden H, Adolfsson R and Winblad B: Histopathological criteria for progressive dementia disorders: clinical-pathological correlation and classification by multivariate data analysis. Acta Neuropathol 74: 209-225, 1987.

22. Petersen RC, Smith GE, Waring SC, Ivnik RJ, Tangalos EG and Kokmen E: Mild cognitive impairment: clinical characterization and outcome. Arch Neurol 56: 303-308, 1999.

23. American Psychiatric Association: Diagnostic and Statistical Manual of Mental Disorders. Third edition, revised edition. American Psychiatric Association, Arlington, VA, 1987.

24. Roman GC, Tatemichi TK, Erkinjuntti T, Cummings JL, Masdeu JC, Garcia JH, Amaducci L, Orgogozo JM, Brun A and Hofman A: Vascular dementia: diagnostic criteria for research studies. Report of the NINDS-AIREN International Workshop. Neurology 43: 250-260, 1993.

25. McKeith IG, Perry EK and Perry RH: Report of the second dementia with Lewy body international workshop: diagnosis and treatment. Consortium on Dementia with Lewy Bodies. Neurology 53: 902-905, 1999.

26. Brun A, Englund E, Gustafson L, Passant U, Mann D, Neary D and Snowden J: Clinical and neuropathological criteria for frontotemporal dementia. The Lund and Manchester Groups. J Neurol Neurosurg Psychiatry 57: 416-418, 1994.

27. Wilhelmsen L, Johansson S, Rosengren A, Wallin I, Dotevall A and Lappas G: Risk factors for cardiovascular disease during the period 1985-1995 in Goteborg, Sweden. The GOT-MONICA Project. J Intern Med 242: 199-211, 1997.
28. Andreasen N, Hesse C, Davidsson P, Minthon L, Wallin A, Winblad B, Vanderstichele H, Vanmechelen E and Blennow K: Cerebrospinal fluid beta-amyloid(1-42) in Alzheimer disease: differences between early- and late-onset Alzheimer disease and stability during the course of disease. Arch Neurol 56: 673-680, 1999.

29. Blennow K, Wallin A, Agren H, Spenger C, Siegfried J and Vanmechelen E: Tau protein in cerebrospinal fluid: a biochemical marker for axonal degeneration in Alzheimer disease? Mol Chem Neuropathol 26: 231-245, 1995.

30. Vanderstichele H, Van Kerschaver E, Hesse C, Davidsson P, Buyse MA, Andreasen N, Minthon L, Wallin A, Blennow K and Vanmechelen E: Standardization of measurement of betaamyloid(1-42) in cerebrospinal fluid and plasma. Amyloid 7: $245-258,2000$

31. Vanmechelen E, Vanderstichele H, Davidsson P, Van Kerschaver E, Van Der Perre B, Sjogren M, Andreasen N and Blennow K: Quantification of tau phosphorylated at threonine 181 in human cerebrospinal fluid: a sandwich ELISA with a synthetic phosphopeptide for standardization. Neurosci Lett 285: 49-52, 2000.

32. Eyre TA, Ducluzeau F, Sneddon TP, Povey S, Bruford EA and Lush MJ: The HUGO Gene Nomenclature Database, 2006 updates. Nucleic Acids Res 34: D319-D321, 2006.

33. Blennow K, Ricksten A, Prince JA, Brookes AJ, Emahazion T, Wasslavik C, Bogdanovic N, Andreasen N, Batsman S, Marcusson J, Nagga K, Wallin A, Regland B, Olofsson H, Hesse C, Davidsson P, Minthon L, Jansson A, Palmqvist L and Rymo L: No association between the alpha2-macroglobulin (A2M) deletion and Alzheimer's disease, and no change in A2M mRNA, protein, or protein expression. J Neural Transm 107: 1065-1079, 2000.

34. Bertram L and Tanzi RE: Alzheimer's disease: one disorder, too many genes? Hum Mol Genet 13: R135-R141, 2004.

35. Poirier J, Davignon J, Bouthillier D, Kogan S, Bertrand P and Gauthier S: Apolipoprotein E polymorphism and Alzheimer's disease. Lancet 342: 697-699, 1993.

36. Strittmatter WJ, Saunders AM, Schmechel D, Pericak-Vance M, Enghild J, Salvesen GS and Roses AD: Apolipoprotein E: highavidity binding to beta-amyloid and increased frequency of type 4 allele in late-onset familial Alzheimer disease. Proc Natl Acad Sci USA 90: 1977-1981, 1993.

37. McCart AE, Mahony D and Rothnagel JA: Alternatively spliced products of the human kinesin light chain 1 (KNS2) gene. Traffic 4: 576-580, 2003

38. Morfini G, Szebenyi G, Elluru R, Ratner N and Brady ST: Glycogen synthase kinase 3 phosphorylates kinesin light chains and negatively regulates kinesin-based motility. EMBO J 21: 281-293, 2002.

39. Woodgett JR: Regulation and functions of the glycogen synthase kinase-3 subfamily. Semin Cancer Biol 5: 269-275, 1994.

40. Pei JJ, Tanaka T, Tung YC, Braak E, Iqbal K and Grundke-Iqbal I: Distribution, levels, and activity of glycogen synthase kinase-3 in the Alzheimer disease brain. J Neuropathol Exp Neurol 56: 70-78, 1997. 